Copyright (C) 2021 University of Bucharest Printed in Romania. All rights reserved

ISSN print: $1224-5984$

ISSN online: $2248-3942$
Rom Biotechnol Lett. 2021; 26(2): 2548-2559

doi: $10.25083 / \mathrm{rbl} / 26.2 / 2548.2559$

Received for publication, February, 4, 2020

Accepted, November, 30, 2020

Original paper

\title{
Environmental stress responses in yeasts and lactic acid bacteria strains isolated from dairy traditional Romanian fermented products
}

\author{
VIORICA CORBU ${ }^{1}$, STEFANA PETRUT ${ }^{1,2}$, TATIANA VASSU ${ }^{1}$, DIANA \\ PELINESCU ${ }^{1}$, IONELA SARBU ${ }^{1}$, ELENA RUSU ${ }^{2}$, ORTANSA CSUTAK ${ }^{1}$
}

${ }^{1}$ University of Bucharest, Faculty of Biology, Department of Genetics, Aleea Portocalelor No. 1-3, 060101 Bucharest, Romania

${ }^{2}$ Titu Maiorescu University, Faculty of Medicine, Preclinic, Department, 67a Gheorghe Petrascu Str., 031593, Bucharest, Romania

\begin{abstract}
During last decades, there is a growing interest for characterizing new microbial strains isolated from various sources (plants, soil and natural fermentative processes), in order to enhance industrial productivity. The aim of the present study was to assess the profile of cell growth parameters and biomass accumulation of 15 newly isolated yeast and lactic acid bacteria (LAB) strains from Romanian spontaneous fermented dairy products under different environmental stress conditions (chemical and physical). On this purpose, the yeast and LAB strains were characterized and identified using MALDI-TOF MS and selected for their biotechnological potential. Cell growth was evaluated in presence of extreme $\mathrm{pH}$ values, temperatures and different $\mathrm{NaCl}$ concentrations. All strains included in this study grew well under their optimal conditions; some of them preferred extreme parameters: acid / very alkaline $\mathrm{pH}$, high temperatures or $\mathrm{NaCl}$ concentration The characterization of microbiota from Romanian spontaneous fermented dairy products might represent a great opportunity for the development of dairy industry using native microorganisms, preserving thus the Romanian biodiversity and cultural heritage.
\end{abstract}

Keywords Romanian fermented dairy products, osmotolerant microorganisms, extreme $\mathrm{pH}$, heat shock resistant microorganisms.

To cite this article: CORBU V, PETRUT S, VASSU T, PELINESCU D, SARBU I, RUSU E, CSUTAK O. Environmental stress responses in yeasts and lactic acid bacteria strains isolated from dairy traditional Romanian fermented products. Rom Biotechnol Lett. 2021; 26(2): 2548-2559. DOI: $10.25083 / \mathrm{rbl} / 26.2 / 2548.2559$

* Corresponding author: STEFANA PETRUT, PhD student, University of Bucharest, Faculty of Biology, Department of Genetics, Aleea Portocalelor No. 1-3, 060101 Bucharest, Romania E-mail: stefana.petrut@gmail.com Tel.: +40726214183 


\section{Introduction}

The production of fermented dairy products through spontaneous fermentation has been used for thousands of years and remains until now one of the main methods used for milk processing and preservation. Spontaneous fermentation allows microbial natural selection by generating a stressful environment in which only those microorganisms that have undergone the necessary metabolic adaptations survives. This process is mainly governed by yeasts belonging to various genera and species, such as: Kluyveromyces lactis, Kluyveromyces marxianus (YU, 2011), Saccharomyces cerevisiae, Saccharomyces boulardii, Pichia kudriatzevii, Yarrowia lipolytica, Debaryomyces hansenii, Candida parapsilosis, Candida tropicalis, Kazachstania unispora (QUIGLEY, 2011; AKABANDA, 2013) and/or lactic acid bacteria (LAB) of which the most representative strains belong to Lactococcus (Lc.) lactis, Lactobacillus (Lb.) casei, Lb. delbruecki, Lb. acidophilus, Lb. rhamnosus, Lb. helveticus, Lb. plantarum, Streptococcus (St.) thermophilus (AKABANDA, 2013). The dairy products are classified in two categories, according to the major group of fermentative microorganisms isolated: (i) milk products obtained through lactic fermentation in which LAB strains occupy the central position and (ii) fungal-lactic fermented products where LAB and yeasts act simultaneously to generate the final product (TAMANG, 2016).

Studies on the dynamics of the microbial population found in spontaneously fermented dairy products have revealed that starter $\mathrm{LAB}$ are mainly involved in the acidification while yeasts, molds and other non-starter $\mathrm{LAB}$ contributing to the organoleptic properties of the products conferring different flavors or textures. Also, some of the microorganisms involved can release beneficial compounds for human health such as: conjugated linoleic acid (CLA) with antioxidative and anti-inflammatory activity and useful for atherogenesis prevention (CHINNADURAI, 2013; PENEDO, 2013); exopolysaccharides (EPS), carbohydrate polymers with positive impact on the human gut microbiota and the immune system (CAGGIANIELLO, 2016); bioactive peptides (peptides mainly derived from casein) that might have antimicrobial, antioxidative, antihypertensive and immunoregulatory activity (FERNÁNDEZ, 2015; HERNÁNDEZLEDESMA, 2011); vitamins (folic acid, biotin, cobalamina.s.o) (PATRING, 2006; SAUBADE, 2017); $\gamma$-aminobutyric acid (GABA- non-protein amino acids) considered to be highly valuable for pharmaceuticals having hypotensive, diuretic and antidiabetic properties (DHAKAL, 2012; HUDEC, 2015; LIM, 2017) and oligosaccharides (prebiotics) that positively influence growth of bifidobacteria (CHEN, 2017; PADILLA, 2015).
The study of the microbiota involved in spontaneous fermentation is of particular importance from several points of view. First of all, it allows isolation of microorganisms that possess specific metabolic adaptations due to the environment influence and, subsequently, can be used to improve different industrial processes without resorting to genetic engineering techniques. Also, traditional/spontaneous fermentation occurs without sterilization that involves a continuous transfer of microorganisms between the processing environment and the fermented product. This represents an interesting point of view since analyzing the microbiota of the fermented products can reflect the microbiota of the environment from specific geographical areas (QVIRIST, 2016).

In Romania, traditionally fermented dairy products represent an important part of the daily diet and can be developed into an international business card reflecting the local specificity and protecting biodiversity (FEUTRY, 2012; ZAMFIR, 2006). The Romanian dairy market, particularly the organic dairy market, is constantly growing, currently reaching 1.3 million euros. Although some of the market leaders have Romanian origins and the production factories are located on the territory of Romania, the microbial strains used in food fermentations are usually from international collections consisting of microbial strains previously isolated from various geographical regions from aboard (JUNGERSEN, 2014). This is mainly due to the limited interest for the characterization of the native microbial biodiversity specific for spontaneous fermented dairy products that can provide unlimited resources and are more suitable for the needs of the inhabitants of this area. Of course, in this context, the interest of the Romanian entrepreneurs for developing the research segment of their businesses represents an important issue.

During food industrial and biotechnological processes, the microorganisms are exposed to different physical and chemical stress conditions involving temperature shocks, extreme $\mathrm{pH}$ and high osmotic pressure induced by high carbohydrates or $\mathrm{NaCl}$ concentrations (LÓPEZ-GONZÁLEZ, 2018). Thus, the main objective of this study represents the characterization of biomass accumulation for 15 newly isolated yeast and LAB strains from traditional Romanian fermented dairy products grown under various stress conditions.

\section{Materials and Methods}

\section{Microbial strains}

A total number of 15 microbial strains, seven yeast strains and eight LAB strains, were isolated from spontaneous fermented milk products from different counties of Romania (Ialomița, Dâmbovița, Bistrița-Năsăud, Ilfov and Mureş) (Table 1). 
Table 1. The 15 isolates and isolation source

\begin{tabular}{|c|c|c|c|}
\hline \multicolumn{2}{|c|}{ Strain } & \multirow{2}{*}{$\begin{array}{c}\text { Source of isolation } \\
\text { Fermented milk }\end{array}$} & \multirow{2}{*}{$\begin{array}{c}\text { County/Region } \\
\text { Ilfov } \\
\end{array}$} \\
\hline \multirow{7}{*}{$\begin{array}{l}\mathrm{Y} \\
\mathrm{E} \\
\mathrm{A} \\
\mathrm{S} \\
\mathrm{T} \\
\mathrm{S}\end{array}$} & Y-L3S & & \\
\hline & Y-DA1 & Fermented milk & Ilfov \\
\hline & Y-SM3 & Sour-cream & Bistrita \\
\hline & Y-CMGB 233 & Fermented milk & Ialomița \\
\hline & Y-CMGB 234 & Cheese & Ialomița \\
\hline & I.orientalisCMGB 224* & Yogurt & Ialomița \\
\hline & I.orientalisCMGB $225^{*}$ & Yogurt & Ialomița \\
\hline \multirow{8}{*}{$\begin{array}{l}\mathrm{L} \\
\mathrm{A} \\
\mathrm{B}\end{array}$} & LAB-Lb20 & Fermented milk & Mureș \\
\hline & LAB-Bz1 & Cheese & Dâmbovița \\
\hline & LAB-U4 & Fermented milk & Dâmboviţa \\
\hline & LAB-SM2 & Sour-cream & Bistrița \\
\hline & LAB-P4 & Fermented milk & Dâmbovița \\
\hline & LAB-Bz6 & Cheese & Dâmbovița \\
\hline & LAB-L4 & Fermented milk & Dâmbovița \\
\hline & LAB-S2b & Sour-cream & Dâmbovița \\
\hline
\end{tabular}

Purification of the strains was done by streaking on YPGA media $(0.5 \%$ yeast extract, $1 \%$ peptone, $0.2 \%$ glucose, $2 \%$ agar) for yeasts and MRSA (2\% glucose, $1 \%$ peptone, $0.5 \%$ meat extract, $0.5 \%$ yeast extract, $0.2 \%$ dipotassium hydrogen phosphate, $0.1 \%$ Tween 80 , $0.2 \%$ diammonium citrate, $0.5 \%$ sodium acetate trihydrate, $0.01 \%$ magnesium sulfate heptahydrate, $0.005 \%$ manganese sulfate tetrahydrate, $1.5 \%$ agar, $\mathrm{pH}=6.5$ ) for LAB strains. After purification, the strains were stored at $-70^{\circ} \mathrm{C}$ in a Revco LegaciTM Refrigeration System (Copeland, U.K) in YPG, respectively MRS broth supplemented with $20 \%(\mathrm{v} / \mathrm{v})$ glycerol added as cryoprotectant, until further experiments. Prior to the beginning of the experiments, each yeast strain was sub-cultured on YPGA slants for 24 hours at $28^{\circ} \mathrm{C}$, while bacterial strains were sub-cultured $(1 \% \mathrm{v} / \mathrm{v})$ in MRS broth for $24 \mathrm{~h}$ at $37^{\circ} \mathrm{C}$.

\section{Bruker MALDI-TOF identification}

For MALDI-TOF MS analysis samples were prepared by resuspending single yeast/bacterial colonies grown on YPGA/MRSA media for $24 \mathrm{~h}$ at $28 / 37^{\circ} \mathrm{C}$, in a matrix solution provided by the manufacturer and subsequently applied to a coded plate. MALDI-TOF MS measurements were acquired according to the manufacturer instructions using a Microflex III instrument (Bruker Daltonik, Bremen, Germany) and compared to the reference mass spectra using MALDI BioTyper Software (Bruker Daltonics). The results were expressed as suggested by the manufacturer using scores ranging from 0 to 3 . Only scores higher than 2 were taken into account as being reliable for microbial identification (IONESCU, 2015; ÁLVAREZ-BUYLLA, 2012).

\section{Growth at different $\mathrm{pH}$ values}

Yeast and LAB strains ability to grow under stress conditions induced by different $\mathrm{pH}$ values (3-12) was determined using YPG/MRS broth with $\mathrm{pH}$ adjusted using a solution of $\mathrm{HCl} 2 \mathrm{~N}$ (for $\mathrm{pH}<6$ ) or $\mathrm{NaOH} 40 \%$ (for $\mathrm{pH}>6$ ). Overnight yeast and $\mathrm{LAB}$ cultures were centrifuged at $7000 \mathrm{rpm}$ for $7 \mathrm{~min}$., washed twice with distilled sterile water and the cell suspensions were adjusted to an OD $600 \mathrm{~nm}=1$ using a spectrophotometer (VilberLourmat). This suspension was used to inoculate $300 \mu \mathrm{L}$ of $\mathrm{pH}$ adjusted YPG/MRS broth to a final concentration of $1 \%$ (v/v). Cell growth was determined by measuring the OD600nm after $24 \mathrm{~h}$ of incubation at $28 / 37^{\circ} \mathrm{C}$ using a Synergy HTX Multi-Mode Reader (Bio-Tek) (PETRUT, 2016). The positive controls were represented by YPG/MRS broth, that have an initial $\mathrm{pH}$ of 6.2 respectively, 6.5.

\section{Growth in osmotic stress conditions}

Dairy food processing is most often associated with exposure of microbial cells to osmotic stress. In order to evaluate the ability of our strains to resist to this kind of stress we used YPG/MRS broth with several $\mathrm{NaCl}$ concentrations $(0.5 \% ; 2 \% ; 5 \% ; 8 \% ; 10 \% ; 12 \%)$. After inoculation of the specific culture media as described above, the OD $600 \mathrm{~nm}$ was determined after $24 \mathrm{~h}$ of incubation at $28 / 37^{\circ} \mathrm{C}$. Positive controls were used to validate the results represented by YPG/MRS broth without $\mathrm{NaCl}$

\section{Growth at different temperature values}

The processes associated with the food industry, usually involve quite large variations in the temperature of the culture media. The ability of yeast and $\mathrm{LAB}$ strains to grow at different temperature values $\left(15^{\circ} \mathrm{C} ; 22^{\circ} \mathrm{C}\right.$; $28^{\circ} \mathrm{C} ; 37^{\circ} \mathrm{C} ; 42^{\circ} \mathrm{C} ; 60^{\circ} \mathrm{C}$ ) was tested by inoculating the yeast/LAB strains in YPG/MRS broth using the same protocol as previously. The microbial growth was monitored by reading the OD $600 \mathrm{~nm}$ after $24 \mathrm{~h}$ of incubation 
(QVIRIST, 2016) and the results were reported to positive controls for which the incubation temperature was $28^{\circ} \mathrm{C}$ for yeasts, respectively, $37^{\circ} \mathrm{C}$ for $\mathrm{LAB}$ strains.

\section{Statistical analysis}

All the experiments were done in triplicates and the results obtained were expressed as mean $\pm \mathrm{SD}(\mathrm{n}=3)$ using Excel tool from Microsoft Office 2016 package.

\section{Results and Discussions}

Yeast and LAB strains isolation and identification

Naturally fermented dairy products continue to be a matter of special interest due to the rich microbial biodiversity, which represents a valuable source of microorganisms harboring. A total number of 15 microbial strains isolated from spontaneous fermented dairy products from different regions of Romania were selected for our study. The strains were identified using Bruker MALDI-TOF Identification System, as previously described. The advantage of Bruker MALDI-TOF Identification System is that it can be used to identify a large number of species or species groups, most of them being characteristic for clinical microbiology laboratories. In this study, we were able to identify 13 yeast and LAB strains (Table 2).

Table 2. MALDI-TOF MS identification of the 15 isolates

\begin{tabular}{|c|c|c|}
\hline \multicolumn{2}{|c|}{ Strain } & \multirow{2}{*}{$\begin{array}{l}\text { MALDI TOF MS identification } \\
\text { Candida krusei }\end{array}$} \\
\hline $\mathrm{Y}$ & Y-L3S & \\
\hline $\mathrm{E}$ & Y-DA1 & Candida parapsilosis \\
\hline $\begin{array}{l}\text { A } \\
\text { C }\end{array}$ & Y-SM3 & Candida krusei \\
\hline $\begin{array}{l}\mathrm{S} \\
\mathrm{T}\end{array}$ & Y-CMGB 233 & Hansenula(Ogataea) polymorpha \\
\hline S & Y-CMGB 234 & Saccharomyces cereviae \\
\hline \multirow{8}{*}{$\begin{array}{l}\mathrm{L} \\
\mathrm{A} \\
\mathrm{B}\end{array}$} & LAB-Lb20 & Lactobacillus rhamnosus \\
\hline & LAB-Bz1 & Lactobacillus plantarum \\
\hline & LAB-U4 & Enterococcus faecalis \\
\hline & LAB-SM2 & Lactobacillus plantarum \\
\hline & LAB-P4 & Lactobacillus paracasei \\
\hline & LAB-Bz6 & Lactobacillus plantarum \\
\hline & LAB-L4 & Enterococcus faecalis \\
\hline & LAB-S2b & Lactobacillus plantarum \\
\hline
\end{tabular}

Regarding the yeast species isolated, three of them were identified as Candida krusei. Many studies debate the taxonomic classification of the members of this species. First, it was associated with P. kudriavzevii (I. orientalis) being considered its anamorphic form. Later, other studies suggested that members of these two species cannot be separated through genome sequencing (DOUGLASS, 2018). However, conventional identification techniques question these assumptions due to a number of differences occurring between the two species, such as the ability to produce ascospores a.s.o (KURTZMAN, 2011). As a consequence, in the present study we will keep the name generated using the MALDI-TOF system, i.e. Candida krusei.

The other yeast strains isolated were determined as belonging to C. parapsilosis, Saccharomyces cerevisiae and Hansenula (Ogataea) polymorpha species. Except $H$. (O.) polymorpha, all these species were previously identified in fermented products and have been used in the dairy industry over time. Therefore, H. (O.) polymorpha can be considered an exception because its main isolation sources are soil, orange juice and sometimes clinical samples (MANFRÃO-NETTO, 2019).
The eight newly isolated LAB strains, previously characterized (morpho-physiological and biochemical data not shown) were taxonomically classified into Lactobacillus and Enterococcus genera (Table 2). The genus Lactobacillus includes the highest number of GRAS (Generally Recognized as Safe) species, many of them having great importance in processes from food industry and human nutrition (SALVETTI, 2012). On the other hand, species belonging to Enterococcus genus are suitable as starter cultures for food biotechnology, with an important role in the development of flavor for different products and other organoleptic characteristics of various fermented foods (PETRUT, 2019).

\section{Assessment of growth parameters profile in diffe- rent environmental stress conditions}

When selecting strains for food fermentation, different aspects, including safety, functional and technological characteristics, have to be taken into consideration (TAMANG, 2016; ZHONG, 2016). Developing new starter cultures is not easy. It is essential to undergo a complex characterization (phenotypic and genotypic) of the strains that are going to be used at industrial scale. Although many microorganisms have great organoleptic 
properties, some of them cannot resist to the manufacturing process which implies huge mechanical, thermal, osmotic stress and also $\mathrm{pH}$ changes or metabolite induced stress (KANDASAMY, 2018). In order to resist to all these challenges, functional microorganisms have developed different mechanisms of adaptation to this environment.

\section{Growth at different $\mathrm{pH}$ values}

During the biotechnological processes, such as milk fermentations, yeasts and bacteria used as starter cultures are exposed to a wide range of stress conditions, among which $\mathrm{pH}$ fluctuations. The ability to grow under these conditions represents an important technological characteristic of these strains, assuring thus their success in the competition with other groups of microorganisms which co-exist in this environment (LARANJO, 2017; AHMED, 2006). Similarly, yeast and LAB strains used in probiotic products must be able to survive in presence of various $\mathrm{pH}$ values characteristics to the gastrointestinal tract (GIT), in order to colonize the GIT of the host and to exert their beneficial properties (PETRUT, 2016; NEMSKA, 2019). Also, resistance to low $\mathrm{pH}$ values is extremely important for biofuel production using food industry wastes since many microbial strains can be used for converting starch to glucose without chemical pre-treatment and during this process low $\mathrm{pH}$ values are frequently encountered (CHAUDHARY, 2017).

Yeast growth is more active at lower $\mathrm{pH}$ values compared to neutral or alkaline $\mathrm{pH}$. According to Figure 1 our yeast strains have an optimal $\mathrm{pH}$ growth value in the range 4.0-8.5. Some differences occurred regarding the resistance of Issatchenkia orientalis strains to extreme $\mathrm{pH}$ conditions. Thus, the strain I. orientalis Y-CMGB 225 presented high values of growth at $\mathrm{pH} 3.0$ while the strain I. orientalis $\mathrm{Y}-\mathrm{CMGB} 224$ presented significant growth at alkaline $\mathrm{pH}$. Also, the strains Candida krusei Y-L3S and Y-SM3 grew very well at $\mathrm{pH}$ 3.0. Significant growth was also recorded for $S$. cerevisiae CMGB-234 with an optimal pH interval between 4.0 and 8.5. Extracellular $\mathrm{pH}$ variation affects yeast cell cycle and viability by influencing $\mathrm{pH}$ homeostasis. Optimal internal $\mathrm{pH}$ maintenance is mainly mediated using cells buffer systems that allow H+ consumption (BRANDÃO, 2014)/extrusion through plasma membrane H+-ATPase (ARIÑO, 2010). Many studies have focused on the characterization of metabolic pathways involved in $\mathrm{pH}$ resistance in yeasts, based mainly on promoting expression of specific genes such as IoGasI (I. orientalis) or ScGasI (S. cerevisiae). These genes encode glycosylphosphatidylinositol (GPI)anchored proteins involved in protecting cells wall integrity when exposed to environmental stress (WADA, 2020). I. orientalis is considered a multiple stress-tolerant yeast, the members of this species showing great variability of stress condition resistance (MATSUSHIKA, 2016). Due to its metabolic versatility, numerous studies have focused on the utility of Issatchenkia species in industrial processes involving high variations of $\mathrm{pH}$ values (TOIVARI, 2013).

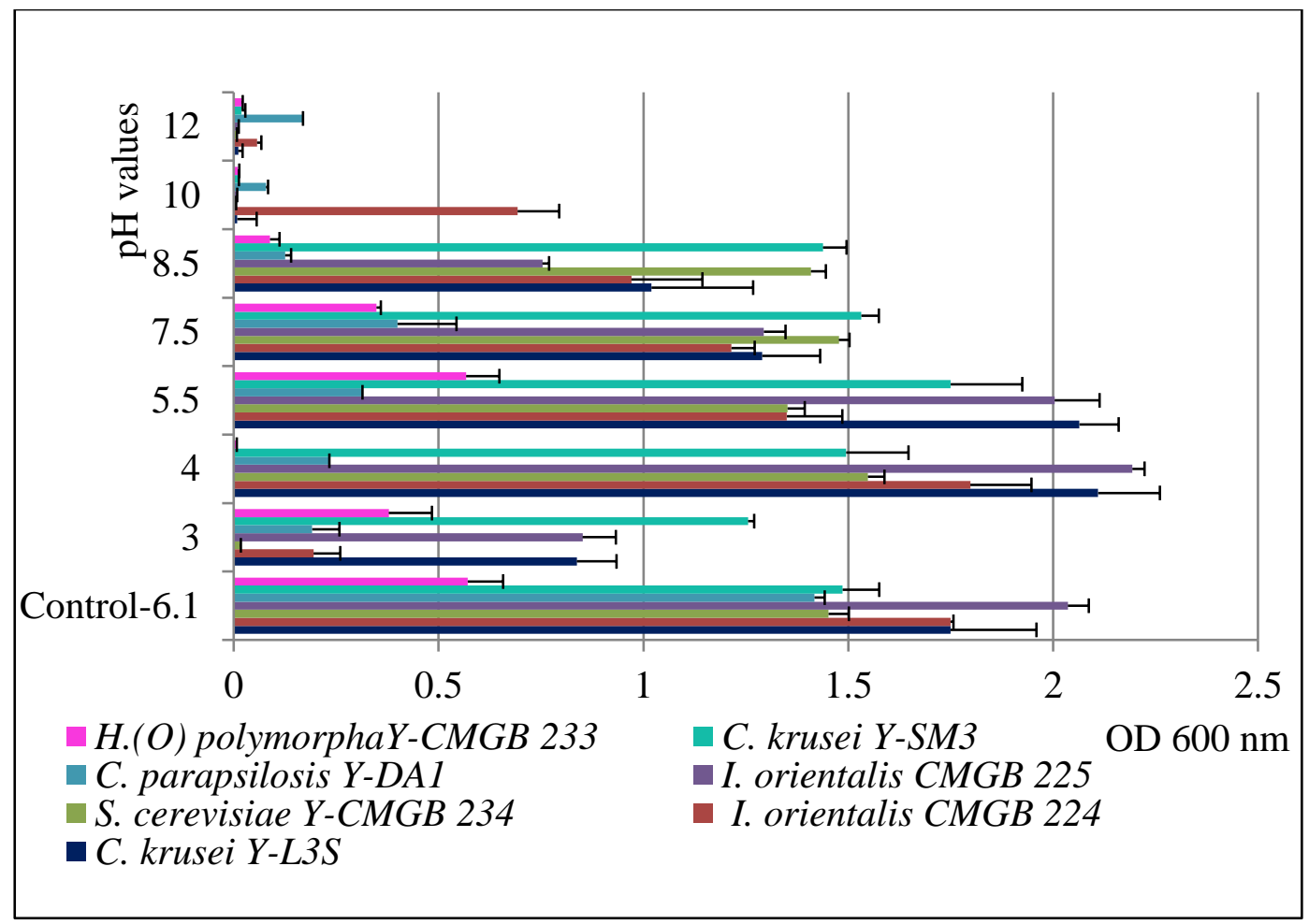

Figure 1. Effect of $\mathrm{pH}$ variation on yeast growth. 
The results obtained revealed different responses of LAB strains to low/ high initial pH values. All tested strains had an optimal growth at $\mathrm{pH}$ range between 5.5 and 7.5, but there were also some strains that grew well at extreme $\mathrm{pH}$ values - acid or alkaline (L4 and U4 - pH 10.0 to 12.0; $\mathrm{SM} 2-\mathrm{pH} 4.0$ ). The analysis of the growth curves of tested
LAB strains, showed that Enterococcus strains LAB-L4 and LAB-U4 have high resistance to $\mathrm{pH} 10.0$ and $\mathrm{pH}$ 12.0, with a maximum OD $600 \mathrm{mn}$ of 1.5 , compared to the other strains that registered a significant reduction of the growth rate (Figure 2).

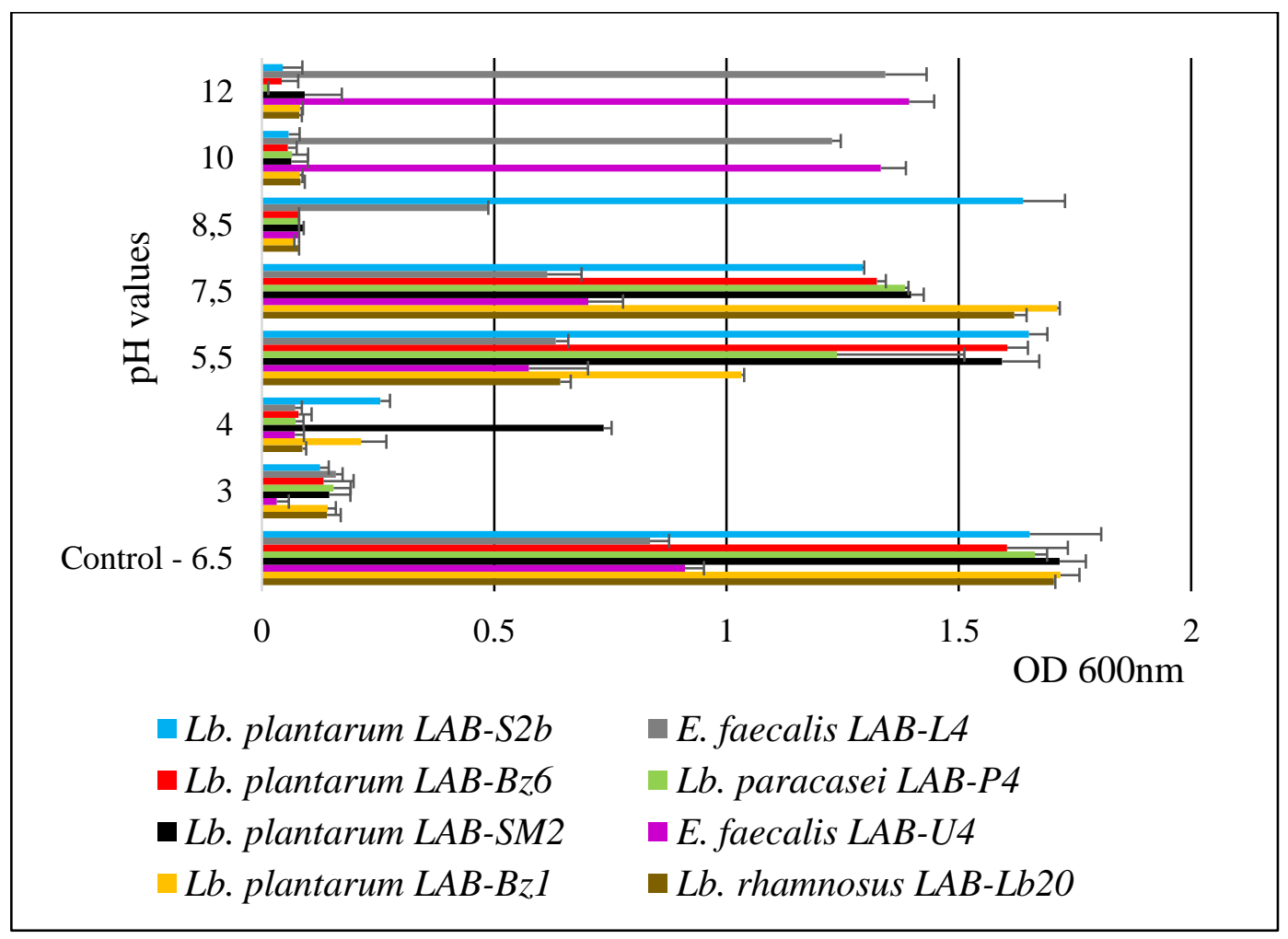

Figure 2. Effect of pH variation on LAB growth.

In contrast, one particular strain, Lactobacillus plantarum LAB-SM2, show preferential growth at acid pH $4.0($ OD $600 \mathrm{mn}=0,735)$ (Figure 2).

The survival of LAB strains in acidic environments has an important impact on health as well as on the economy. Intrinsic resistance to acidic conditions is a relatively rare ability, but there are studies showing species of Lactobacillus and Bifidobacterium genera are among the most resistant to such conditions (COTTER, 2003; NEMSKA, 2019). The mechanisms used by LAB to survive at low $\mathrm{pH}$ stress conditions are very different, three main systems being described as involved in $\mathrm{pH}$ homeostasis: H+ - ATPase proton pump, ADI (arginine deaminase) and GAD (glutamate decarboxylase) systems (COTTER, 2003; HUTKINS, 1993).

On the other hand, growth at high $\mathrm{pH}$ values was associated with an increased energetic level that help the bacterial cells maintain their physiological state. At higher $\mathrm{pH}$, metabolic conversions take place at a much faster rate in LAB cells, i.e. decomposing sugars, citric acid and tartaric acid which lead to acetic acid production. These characteristics may represent a benefit for the production of starter cultures used in obtaining fermented products, due to a better control of the quality of the cultures before using them in the food industry (RAULT, 2009).

\section{Growth at different $\mathrm{NaCl}$ concentrations}

Sodium chloride $(\mathrm{NaCl})$ is the most common curing salt used in fermented products manufacture, acting as a preservative and contributing to the development of the desirable flavor of the foods (CHIKTHIMMAH, 2001). Therefore, we evaluated the resistance of our strains to various $\mathrm{NaCl}$ concentrations. The results (Figure 3 and Figure 4) revealed that, while small amounts of $\mathrm{NaCl}$ $(0.5$ to $5 \%)$ are well tolerated by most of the strains, higher concentrations of $\mathrm{NaCl}(>8 \%)$ inhibited their growth.

Sodium chloride $(\mathrm{NaCl})$ exhibits both ionic and hyperosmotic stress, the yeasts presenting similar mechanisms of response to these two types of stress. Ion homeostasis and osmotic regulation in yeasts is mediated via two different signaling pathways: calcineurin pathways and the high osmolarity glycerol pathway (HOG), which in fact are interdependent (RODRÍGUEZ-PEÑA, 2010). Physiologically, the activation of these signaling pathways is manifested by shrinking the cells to limit the osmotic pressure followed by the accumulation of counteracting 
solutes and restoring the initial physiological state of the cells.

The yeast strains, particularly I. orientalis Y-SM3 and C. parapsilosis Y-DA1, showed high resistance to $\mathrm{NaCl}$ in concentration of $8 \%$. The strains C. krusei Y-L3S, C. krusei Y-SM3, C. parapsilosis Y-DA1 and H. (O.) polymorpha CMGB 233 exhibited higher biomass accumulation at $0.5 \% \mathrm{NaCl}$ compared to the control. This implies that these strains are not only halotolerant, but small concentrations of salts can promote cellular growth (Figure 3).
Although $H$. (O.) polymorpha is considered an exception among microorganisms isolated from dairy products since it is not able to utilize lactose or lactic acid for growth or fermentation (two important characteristics of microorganisms from this niche), it is characterized by as a highly stress tolerant yeast (KURTZMAN, 2011). The presence of this species in traditional fermented foods might have two explanations: their ability to utilize secondary metabolites produced by fermentative strains for growth, respectively, their appearance by transfer from the producing environment (MANFRÃO-NETTO, 2019).

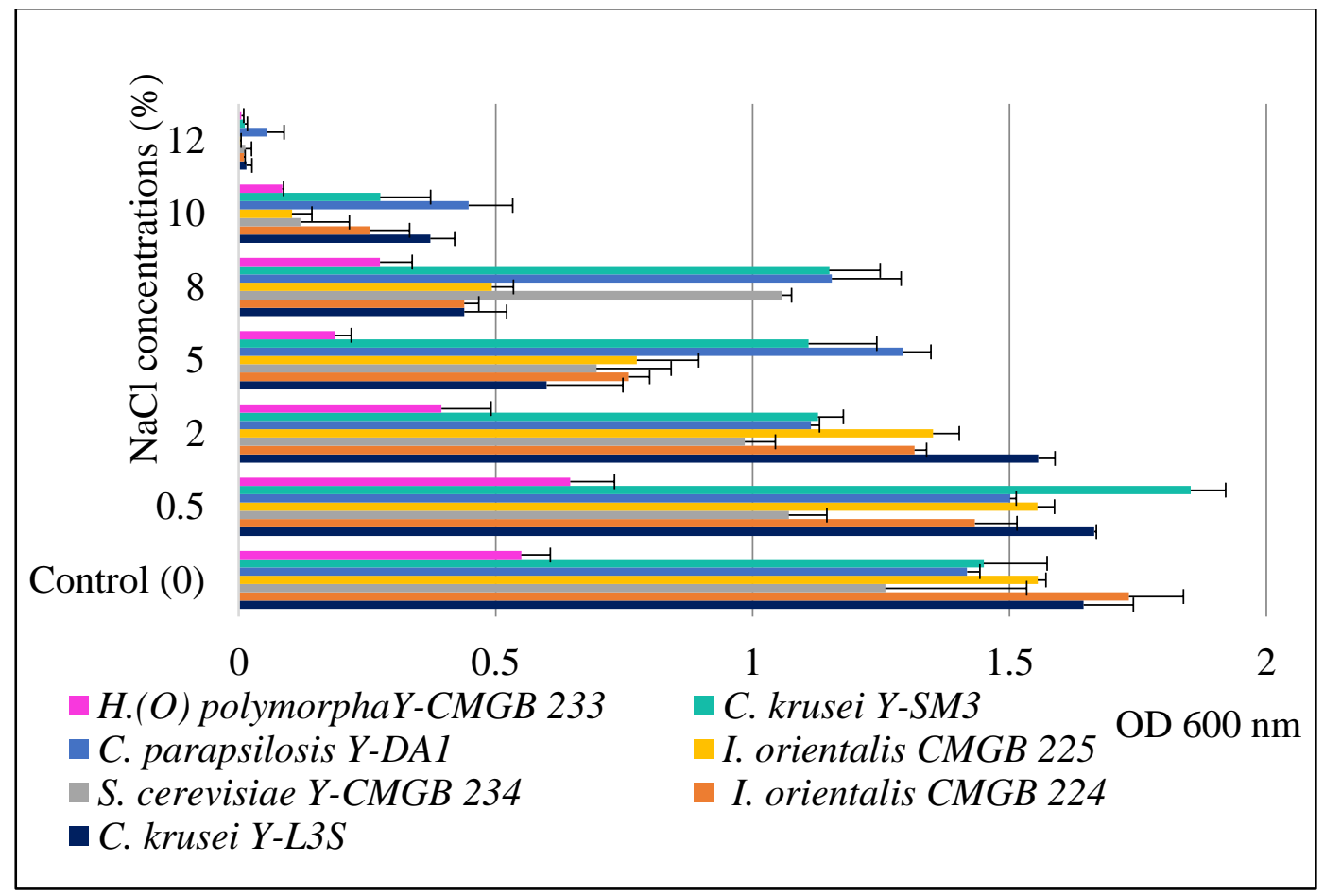

Figure 3. Influence of $\mathrm{NaCl}$ concentrations on yeast growth.

The other yeast species (I. orientalis, C. parapsilosis, C. parapsilosis) are often characterized as belonging to this ecological niche. Therefore, their resistance to stress conditions induced by high $\mathrm{NaCl}$ concentrations is not surprising, recommending them as possible starter cultures for dairy industry.

A similar situation is encountered at LAB strains (Figure 4) that showed an optimal growth at $\mathrm{NaCl}$ concentrations of $2 \%$, which also seemed to promote the growth of four strains (LAB-S2b, LAB-SM2, LAB-Bz1 and LAB-Bz6) up to OD $600 \mathrm{~nm}=2$. Sensitivity of bacterial cultures to salt addition is strongly dependent on bacterial species and strain, and therefore concentrations of $\mathrm{NaCl}$ can have either stimulating or inhibitory effect on bacterial metabolic activity. Species belonging to Lactobacillus group, Lactococcus or even Streptococcus genera were found to be able to grow at up to $4 \%$ of $\mathrm{NaCl}$ (MEDVEĎOVÁ, 2019).
It is interesting that the $\mathrm{LAB}$ strains were more affected by the addition of high $\mathrm{NaCl}$ concentrations ( 8 and $10 \%$ ) compared with the yeasts, most probably due to the changes in cellular metabolism because of its osmotic effect and to the structure of surface proteins of the cells (ARIHARA, 2000).

\section{Growth at various temperatures}

Temperature is among the most important factors for manufacturing processes in food industry (MEDVEĎOVÁ, 2019). Temperature variation has a severe effect on microbial growth by affecting the growth rate, the enzymatic activity, cell composition or nutritional requirements or indirectly, by changing the solubility of some molecules and the length of the lag phase and population of microbial species.

Most of the yeasts are mesophilic meaning that they grow best at temperatures between 20 and $30^{\circ} \mathrm{C}$. Our strains grew best at $28^{\circ} \mathrm{C}$ but high OD values were registered also at $37^{\circ} \mathrm{C}$ and $20^{\circ} \mathrm{C}$ (Figure 5). 


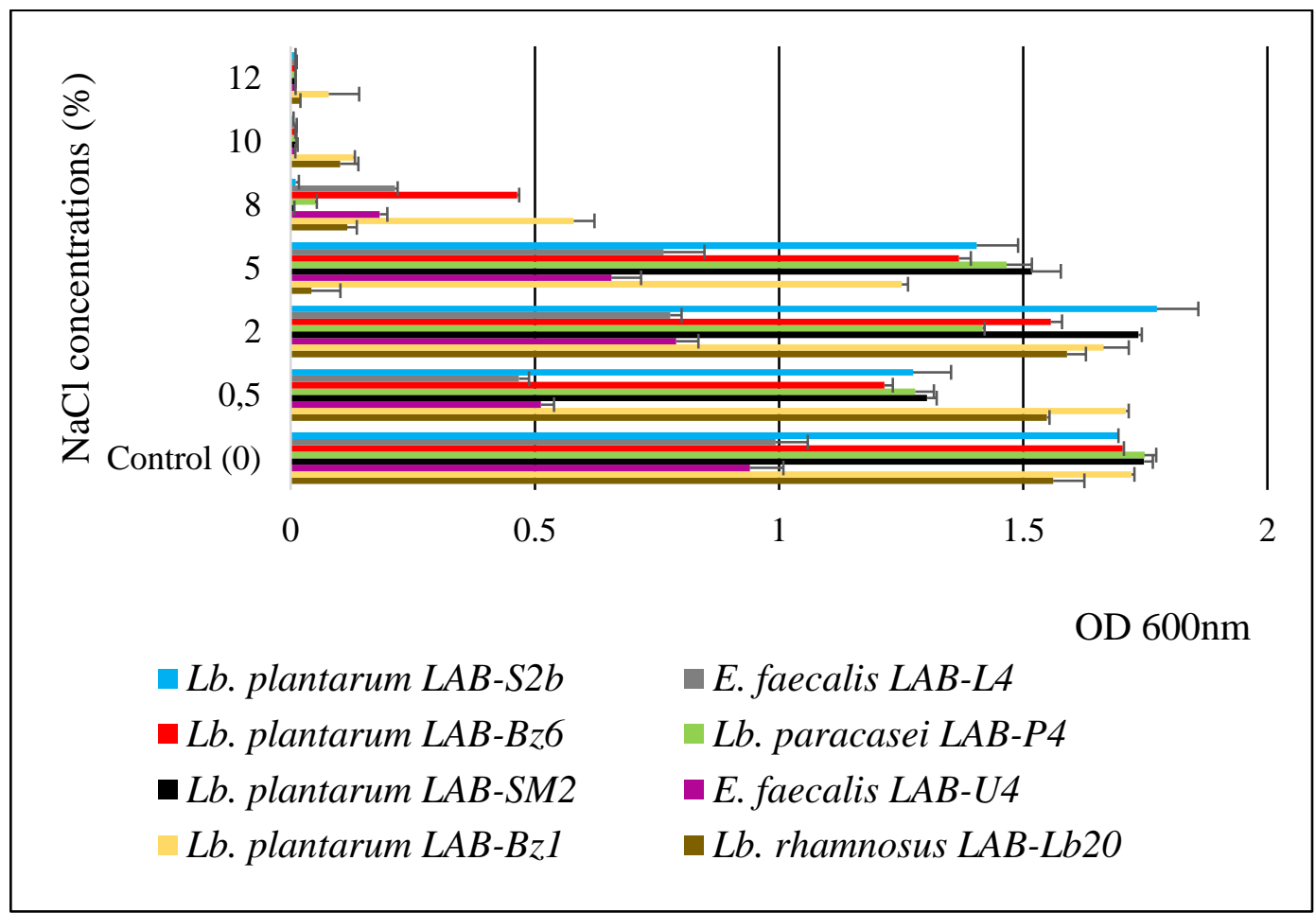

Figure 4. Influence of $\mathrm{NaCl}$ concentrations on $\mathrm{LAB}$ growth.

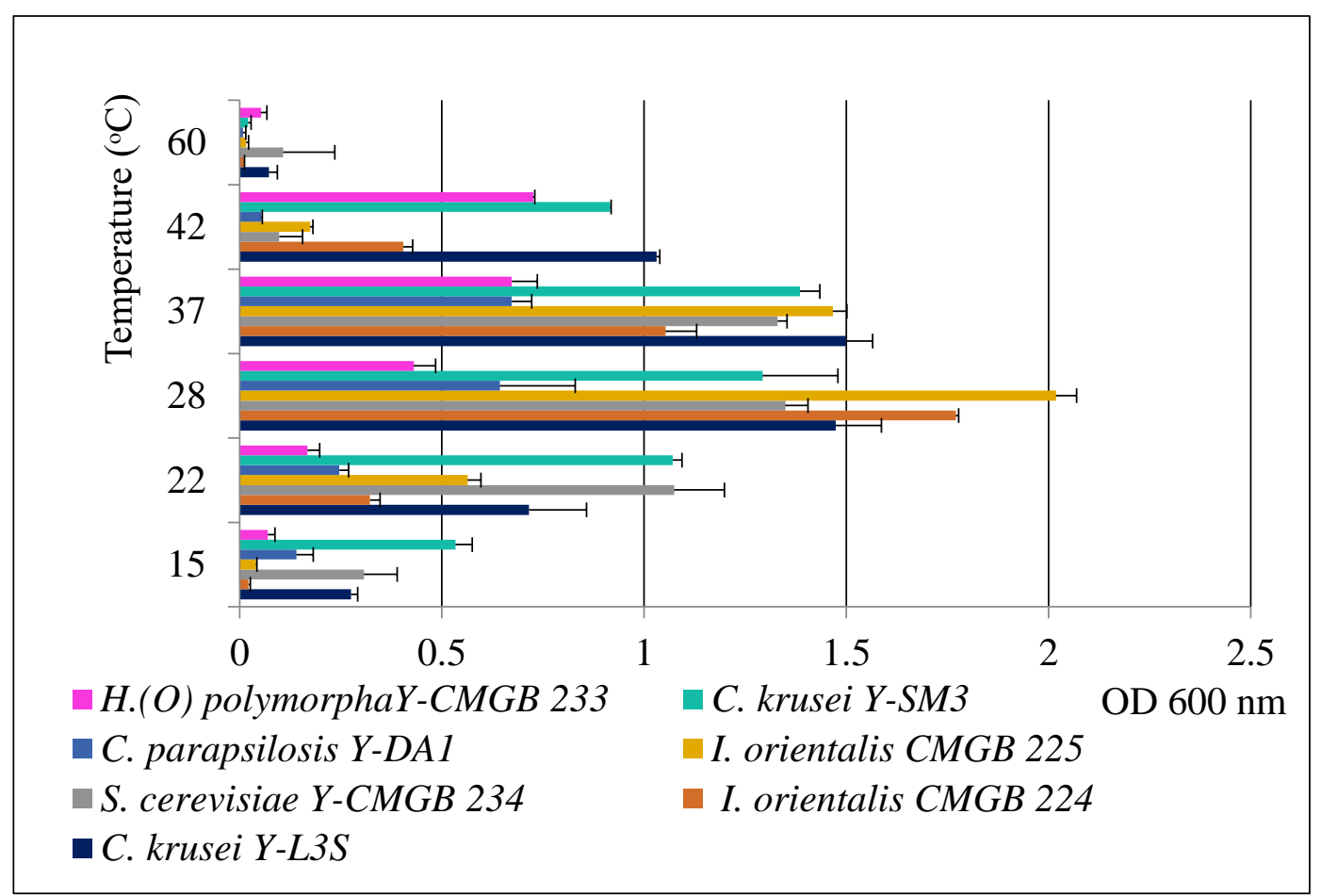

Figure 5. Yeast cultures growth profiles at different temperature values.

The strains $H$. (O.) polymorpha $C M G B 233$ and C. krusei Y-SM3 showed good growth also at $42^{\circ} \mathrm{C}$, an important characteristic, this temperature being considered a niche for thermotolerant and thermophilic yeasts.
H. (O.) polymorpha has unique characteristics being able to grow at temperatures values between 30 to $50^{\circ} \mathrm{C}$ due to a highly efficient mechanism of heat resistance that involves both the expression of heat-shock protein genes and genes 
encoding enzymes from trehalose biosynthesis pathway (ISHCHUK, 2009). Similar physiological behavior was reported for C. krusei. This species can accumulate high amount of trehalose and glycerol when exposed to heat stress, which emphasize the biotechnological importance of this species, since both compounds are of special value in food, cosmetic and medical industry (ISHCHUK, 2009). Environments with temperature above $60^{\circ} \mathrm{C}$ are not suitable for yeasts since this temperature usually affects the stability of the organelles membranes within eukaryote cells.

As shown in Figure 6 the optimal growth temperature for most of the LAB strains analyzed were in the range $28-37^{\circ} \mathrm{C}$. On the contrary, for some strains a good growth, up to $1.5 \mathrm{OD} 600 \mathrm{~nm}$, was observed at temperatures out of this range: $\mathrm{LAB}-\mathrm{Lb} 20$ at $42^{\circ} \mathrm{C}$; LAB-SM2 and LAB-S $2 b$ at $22^{\circ} \mathrm{C}$ (Figure 6).

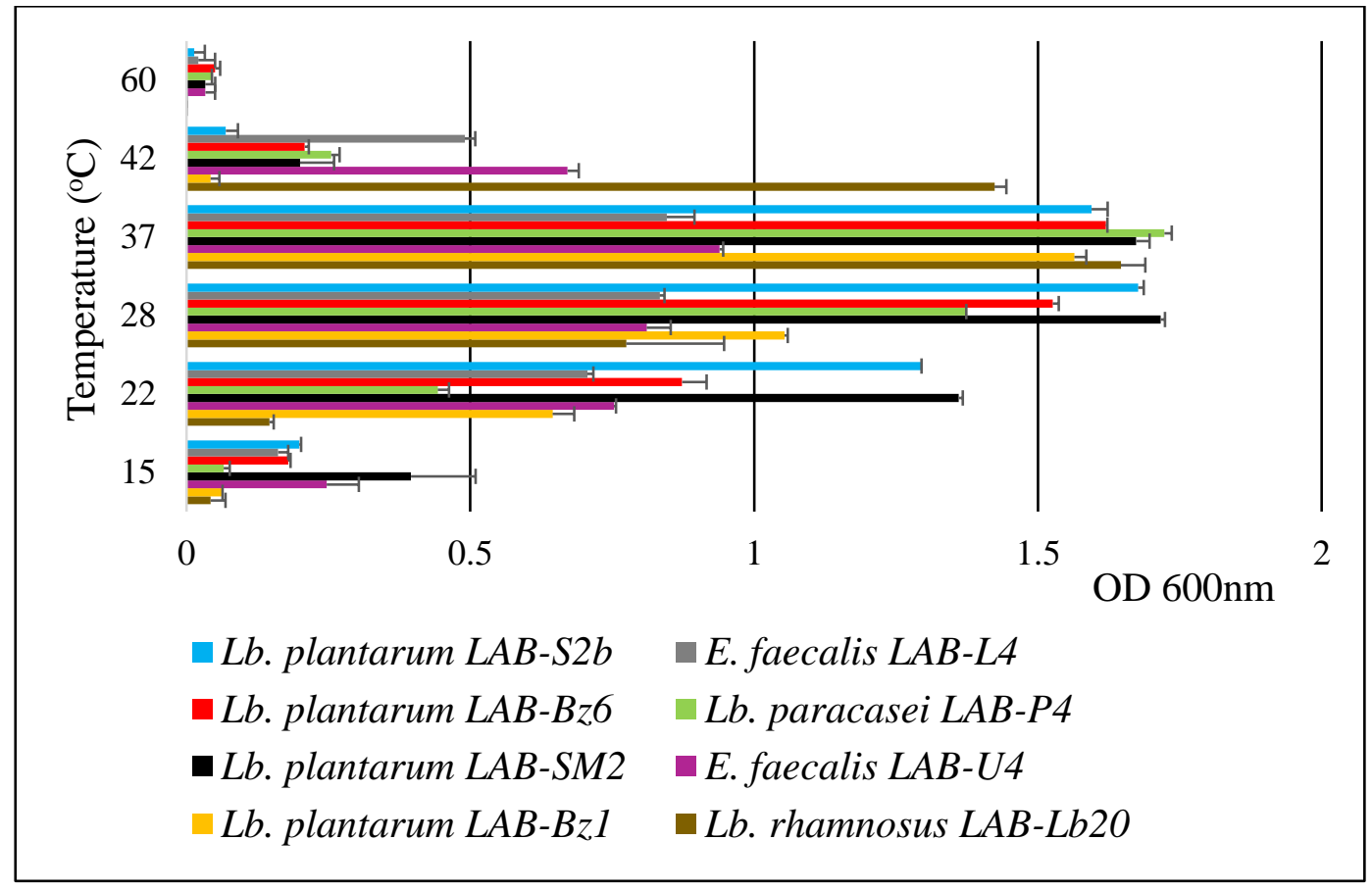

Figure 6. LAB cultures growth profiles at different temperature values.

Although LAB are mesophilic in nature, the temperature range of these microorganisms varies, some species growing well at low or high temperatures. It was shown that low or suboptimal temperatures significantly reduce the dynamic of bacterial populations, as well as the production of lactic acid (slow or absent at temperature less than $20^{\circ} \mathrm{C}$ ) or other inhibitory compounds (AGUILAR, 2010; RUSU, 2016). Nevertheless, other studies reported that LAB strains with growth at low temperature show higher survival rate during long-term conservation (freezing at $-70^{\circ} \mathrm{C}$ ) (AHMED, 2006).

Growth is inhibited at temperatures higher than $40^{\circ} \mathrm{C}$ for most of the LAB species, but there were characterized some Lactobacillus species which had a good rate of biomass accumulation at temperatures up to $53^{\circ} \mathrm{C}$. These metabolic characteristics are valuable for food industry since the ability of starter cultures to produce organic acids, volatile compounds or carbon dioxide, with a great importance in flavor and texture development, is temperature dependent (ØSTLIE, 2005).

\section{Conclusions}

Dairy fermented products play a vital socioeconomic role having a huge rising international market due to its impressive role for human health. Although is a welldeveloped market, the main players must constantly improve their products in terms of aroma and flavor to meet the increasingly diversified needs of their customers. Traditional fermented foods represent a great source of resources for improving industrial production of dairy products regarding their organoleptic properties (hence the importance of characterizing wild strains from raw materials).

The results of the present study revealed that the growth requirements of yeast and LAB strains are different and complex, showing strain specificity. Although all analyzed strains grew well under their optimal conditions, some of them preferred extreme parameters: acid/very alkaline $\mathrm{pH}$, high temperatures or $\mathrm{NaCl}$ concentration.

The yeast strains I. orientalis CMGB 225 and C. krusei Y-L3S and Y-SM3 along with the LAB strain 
Lb. plantarum LAB-SM2 showed high growth when exposed to low $\mathrm{pH}$ (3 respectively, 4) and $37^{\circ} \mathrm{C}$, representing an important basis for further studies regarding their use in biomedicine. The strains C. parapsilosis Y-DA1, H. (O) polymorpha CMGB233, S. cerevisiae CMGB234, Lb. plantarum LAB-S2b, Lb. plantarum LAB-SM2, Lb. plantarum LAB-Bz1 and Lb. plantarum LAB-Bz6 exhibited high resistance to osmotic and $\mathrm{pH}$ stress, fact that recommend them for improvement of the biotechnological processes related to the food industry. Among these, H. $(O)$ polymorpha CMGB233 proved to be an interesting candidate with valuable applications in industrial processes even though its occurrence in dairy products is mainly due to the transfer from the working environment.

Our results concerning the ability of newly isolated yeast and LAB strains to adapt to stressful environmental conditions helped us to select the best adaptive strains for further studies concerning the production of several metabolites important for food texture or health (exopolysaccharides or biologically active compounds) and for co-cultivation studies in order to develop a mixed starter culture.

\section{Conflict of Interest}

The authors have no conflict of interest to declare.

\section{References}

1. AGUILAR C, KLOTZ B. Effect of the temperature on the antagonistic activity of lactic acid bacteria against Escherichia coli and Listeria monocytogenes. J. Food Safety. 2010; 30 (4): 996-1015. doi: 10.1111/j.17454565.2010.00257.x.

2. AHMED T, KANWAL R, AYUB N. Influence of temperature on growth pattern of Lactococcus lactis, Streptococcus cremoris and Lactobacillus acidophilus isolated from camel milk. Biotechnology. 2006; 5 (4): 481-486.

3. AKABANDA F, OWUSU-KWARTENG J, TANODEBRAH K, GLOVER RL, NIELSEN DS, JESPERSEN L. Taxonomic and molecular characterization of lactic acid bacteria and yeasts in nunu, a Ghanaian fermented milk product. Food Microbiol. 2013; 34 (2): 277-283. doi: 10.1016/j.fm.2012.09.025.

4. ÁLVAREZ-BUYLLA A, CULEBRAS E, PİCAZO JJ. Identification of Acinetobacter species: is Bruker biotyper MALDI-TOF mass spectrometry a good alternative to molecular techniques?. J. Infect. Genet. Evol. 2012; 12 (2): 345-349. doi: 10.1016/j.meegid. 2012.01.002.

5. ARİHARA K, ITOH M. UV-induced Lactobacillus gasseri mutants resisting sodium chloride and sodium nitrite for meat fermentation. Int. J. Food Microbiol. 2000; 56 (2-3): 227-230. doi: 10.1016/S0168-1605(99) 00206-8.
6. ARIÑO J. Integrative responses to high $\mathrm{pH}$ stress in S. cerevisiae. OMICS, 2010; 14 (5): 517-523. doi: 10.1089/omi.2010.0044.

7. BRANDÃO RL, ROSA JCC, NICOLI JR, ALMEIDA MVZ et al. Investigating acid stress response in different Saccharomyces strains. J Mycol 2014; 1-9. doi: 10.1155/2014/178274.

8. CAGGİANİLlO $\mathrm{G}$, KLEEREBEZEM M, SPANO G. Exopolysaccharides produced by lactic acid bacteria: from health-promoting benefits to stress tolerance mechanisms. Appl. Microbiol. Biotechnol. 2014; 100 (9): 3877-3886. doi: 10.1007/s00253-0167471-2.

9. CHAUDHARY A, KARITA S. Screening of yeast isolates from flowers for effective ethanol production. Turk. J. Biol. 2017; 41 (6): 890-900. doi: 10.3906/biy1704-7.

10. CHEN XY, GÄNZLE MG. 2017. Lactose and lactosederived oligosaccharides: More than prebiotics?. Int Dairy J. 2017; 67: 61-72. doi: 10.1016/j.idairyj.2016. 10.001 .

11. CHİKTHİMMAH N, ANANTHESWARAN RC, ROBERTS RF, MILLS EW et al. Influence of sodium chloride on growth of lactic acid bacteria and subsequent destruction of Escherichia coli O157: H7 during processing of Lebanon bologna. J. Food Prot. 2014; 64 (8): 1145-1150. doi: 10.4315/0362-028X64.8.1145.

12. CHINNADURAI KH, KANWAL K, TYAGI AK, STANTON C, ROSS P. 2013. High conjugated linoleic acid enriched ghee (clarified butter) increases the antioxidant and antiatherogenic potency in female Wistar rats. Lipids Health Dis. 2013; 12 (1) 121: 1-9. doi: 10.1186/1476-511X-12-121.

13. COTTER PD, HILL C. Surviving the acid test: Responses of gram-positive bacteria to low pH. Mol. Biol. Rev. 200367 (3): 429-453. doi: 10.1128/mmbr. 67.3.429-453.2003.

14. DHAKAL R, BAJPAİ VK, BAEK KH. Production of GABA ( $\gamma$-aminobutyric acid) by microorganisms: a review. Braz. J Microbiol. 2012; 43(4): 1230-1241. doi: 10.1590/S1517-83822012000400001.

15. DOUGLASS A, OFFEİ PB, BRAUN-GALLEANİ S, COUGHLAN AY, et al. Population genomics shows no distinction between pathogenic Candida krusei and environmental Pichia kudriavzevii: One species, four names. PLoS Pathogens; 2018; 14 (7): 1-27. doi: 10.1371/journal.ppat.1007138.

16. FERNANDEZ MJ, HUDSON A, KORPELA R, DE LOS REYES-GAVILAN CG. Impact on human health of microorganisms present in fermented dairy products: an overview. Biomed Res Int, 2015; 1-13. doi: $10.1155 / 2015 / 412714$.

17. FEUTRY F, ONECA M, BERTHIER F, TORRE P. Biodiversity and growth dynamics of lactic acid bacteria in artisanal PDO Ossau-Iraty cheeses made from raw ewe's milk with different starters. Food Microbiol. 2012; 29 (1): 33-42. doi: 10.1016/j.fm. 2011.08.011 
18. HERNÁNDEZ-LEDESMA B, DEL MAR CONTRERAS M, RECIO I. Antihypertensive peptides: production, bioavailability and incorporation into foods. Adv. Colloid Interface Sci. 2011; 165 (1): 23-35. doi: 10.1016/j.fm.2011.08.011

19. HUDEC J, KOBIDA L, ČANIGOVÁ M, LACKOBARTOŠOVÁ $M$ et al. Production of $\gamma$-aminobutyric acid by microorganisms from different food sources. J. Sci. Food Agric. 2015; 95 (6): 1190-1198. doi: 10.1002/jsfa.6807.

20. HUTKINS R, NANNEN W. pH homeostasis in lactic acid bacteria. J. Dairy Sci. 1993; 76 (8): 2354-2365. doi: 10.3168/jds.S0022-0302(93)77573-6

21. IONESCU D, CHIFIRIUC MC, IONESCU B, CRISTEA VC et al. Frequency and phenotypic virulence features of Streptococcus pyogees strains isolated from throat carriage in Romanian population. Rom Biotech Lett 2015; 20 (3): 10470-10478.

22. ISHCHUK OP, VORONOVSKY AY, ABBAS CA, SIBIIRNY AA. Construction of Hansenula polymorpha strains with improved thermotolerance. Biotechnol. Bioeng. 2009; 104 (5): 911-919. doi: 10.1002/bit. 22457.

23. JUNGERSEN M, WIND A, JOHANSEN E, CHRISTENSEN JE. The Science behind the probiotic strain Bifidobacterium animalis subsp. Lactis BB-12®. Microorganisms. 2014; 2 (2): 92-110. doi: 10.3390/microorganisms2020092.

24. KANDASAMY S, KAVITAKE D, SHETTY PH, 2018. Lactic acid bacteria and yeasts as starter cultures for fermented foods and their role in commercialization of fermented foods. In Innovations in Technologies for Fermented Food and Beverage Industries, Springer, Cham.

25. KURTZMAN C, FELL JW, BOEKHOUT T, 2011. The yeasts: a taxonomic study. $5^{\text {th }}$ ed. Elsevier.

26. LARANJO M, ELIAS M, FRAQUEZA MJ. The use of starter cultures in traditional meat products. J. Food Qual 2017: 1-18. doi: 10.1155/2017/9546026.

27. LIM HS, CHA IT, ROH SW, SHIN HH, SEO MJ. Enhanced production of gamma-aminobutyric acid by optimizing culture conditions of Lactobacillus brevis HYE1 isolated from kimchi, a Korean fermented food. J Microbiol. Biotechnol. 2017; 27 (3): 450-459. doi: 10.4014/jmb.1610.10008.

28. LÓPEZ-GONZÁLEZ MJ, ESCOBEDO S, RODRÍGUEZ A, NEVES AR et al. Adaptive evolution of industrial Lactococcus lactis under cell envelope stress provides phenotypic diversity. Front Microbiol. 2018; 9, 2654: 1-17. doi: 10.3389/fmicb. 2018.02654.

29. MANFRÃO-NETTO JH, GOMES AM, PARACHIN NS. Advances in using Hansenula polymorpha as chassis for recombinant protein production. Front. Bioeng. Biotechnol. 2019; 7, 94: 1-13. doi: 10.3389/ fbioe.2019.00094.

30. MATSUSHIKA A, NEGİ K, SUZUKİ T, GOSHIMA T, HOSHINO T. Identification and characterization of a novel Issatchenkia orientalis GPI-Anchored protein,
IoGas 1 , required for resistance to low $\mathrm{pH}$ and salt stress. Plos One. 2016; 11 (9): 1-25. doi: 10.1371/ journal.pone.0161888.

31. MEDVEĎOVÁ A, ŠİPOŠOVÁ P, MANČUŠKOVÁ T, VALÍK L. The effect of salt and temperature on the growth of Fresco culture. Fermentation. 2019; 5 (1): 1-10. doi: 10.3390/fermentation5010002.

32. NEMSKA V, LOGAR P, RASHEVA T, SHOLEVA Z et al. Functional characteristics of lactobacilli from traditional Bulgarian fermented milk products. Turk. $J$. Biol. 2019; 43 (2): 148-153. doi: 10.3906/biy-1808-34.

33. ØSTLİE HM, TREİMO J, NARVHUS JA. 2005. Effect of temperature on growth and metabolism of probiotic bacteria in milk. Int. Dairy J. 2005; 15 (10): 989-997. doi: 10.1016/j.idairyj.2004.08.015.

34. PADILLA B, FRAU F, RUIZ-MATUTE AI, MONTILLA A et al. Production of lactulose oligosaccharides by isomerisation of transgalactosylated cheese whey permeate obtained by $\beta$-galactosidases from dairy Kluyveromyces. J Dairy Res, 201582 (3): 356-364. doi: 10.1017/S0022029915000217.

35. PATRING JD, HJORTMO SB, JASTREBOVA JA, SVENSSON UK et al. Characterization and quantification of folates produced by yeast strains isolated from kefir granules. Eur. Food Res. Technol. 2006; 223 (5): 633-637. doi: 10.1007/s00217-005-0245-1.

36. PENEDO LA, NUNES JC, GAMA MAS, LEITE PEC et al. Intake of butter naturally enriched with cis9, trans 11 conjugated linoleic acid reduces systemic inflammatory mediators in healthy young adults. $J$ Nutr Biochem 2013; 24 (12): 2144-2151. doi: 10.1016/ j.jnutbio.2013.08.006.

37. PETRUT S, RUSU E, TUDORACHE I, PELINESCU $\mathrm{D}$ et al. Influence of various carbon sources on growth and biomass accumulation of some lactic acid bacteria strains. Rev. Chim. (Bucharest). 2019; 70: 2434-2438. doi: 10.37358/RC.19.7.7356.

38. PETRUT S, SARBU I, IONESCU R, VASSU T et al. Characterization of probiotic potential of some lactic acid bacteria strains isolated from fermented vegetables. Annals. Food Sci. Tech. 201617 (2): 433-438.

39. QUIGLEY L, O'SULLIVAN O, BERESFORD TP, ROSS RP et al. Molecular approaches to analysing the microbial composition of raw milk and raw milk cheese. Int. J. Food Microbiol. 2011; 150 (2-3): 81-94. doi: 10.1016/j.ijfoodmicro.2011.08.001.

40. QVIRIST LA, DE FILIPPO C, STRATI F, STEFANINI I et al. Isolation, identification and characterization of yeasts from fermented goat milk of the Yaghnob Valley in Tajikistan. Front Microbiol. 2016; 7, 1690: 1-17. doi: 10.3389/fmicb.2016.01690.

41. RAULT A, BOUIX M, BÉAL C. Fermentation $\mathrm{pH}$ influences the physiological-state dynamics of Lactobacillus bulgaricus CFL1 during pH-controlled culture. Appl. Environ. Microbiol. 2009; 75 (13): 4374-4381. doi: 10.1128/AEM.02725-08.

42. RODRÍGUEZ-PEÑA JM, GARCÍA R, NOMBELA C, ARROYO J. Thehigh-osmolarity glycerol (HOG) 
and cell wall integrity (CWI) signalling pathway sinterplay: a yeast dialogue between MAPK routes. Yeast. 2010; 27 (8): 495-502. doi: 10.1002/yea.1792.

43. RUSU E, SARBU I, CRISTESCU C, COCULESCU BI et al. Highlighting the antimicrobial activity of organic compounds isolated from some strains of lactic acid bacteria. Rev. Chim. (Bucharest). 2016; 67: 2417-2421.

44. SALVETTİ E, TORRİANI S, FELİS GE. The genus Lactobacillus: a taxonomic update. Probiotics Antimicrob. Proteins, 2012; 4 (4): 217-226. doi: 10.1007/ s12602-012-9117-8.

45. SAUBADE F, HEMERY YM, GUYOT JP, HUMBLOT $C$. Lactic acid fermentation as a tool for increasing the folate content of foods. Crit Rev Food Sci Nutr. 2017; 57 (18): 3894-3910. doi: 10.1080/10408398.2016.1192986.

46. TAMANG JP, WATANABE K, HOLZAPFEL WH. Diversity of microorganisms in global fermented foods and beverages. Front. Microbiol. 2016. 7, 377: 1-28. doi: 10.3389/fmicb.2016.00377.

47. TOIVARI M, VEHKOMÄKI ML, NYGÅD Y, PENTTILÄ $\mathrm{M}$ et al. Low pH D-xylonate production with Pichia kudriavzevii. Bioresource Technol. 2013; 133: 555-562. doi: 10.1016/j.biortech.2013.01.157.

48. WADA K, FUJIII T, AKİTA H, MATSUSHIKA A. IoGAS1, a GPI-anchored protein derived from Issatchenkia orientalis, confers tolerance of Saccharomyces cerevisiae to multiple acids. Applied Biochem. Biotechnol. 2020; 190 (4): 1349-1359. doi: 10.1007/ s12010-019-03187-8.

49. YU J, WANG WH, MENGHE BLG, JIRİ MT et al. Diversity of lactic acid bacteria associated with traditional fermented dairy products in Mongolia. J. Dairy Sci. 2011. 94 (7): 3229-3241. doi: 10.3168/ jds.2010-3727.

50. ZAMFIR M, VANCANNEYT M, MAKRAS L, VANINGELGEM F et al. Biodiversity of lactic acid bacteria in Romanian dairy products. Syst Appl Microbiol. 2006; 29 (6): 487-495. doi: 10.1016/ j.syapm.2005.10.002.

51. ZHONG Z, HOU Q, KWOK L, YU Z et al. Bacterial microbiota compositions of naturally fermented milk are shaped by both geographic origin and sample type. J. Dairy Sci. 2016; 99 (10): 7832-7841. doi: 10.3168/jds.2015-10825. 